\title{
In situ approaches show the limitation of the spoilage potential of Juniperus phoenicea L. essential oil against cold-tolerant Pseudomonas fluorescens KM24
}

\author{
Kamila Myszka ${ }^{1}$ (D) Natalia Tomaś ${ }^{1} \cdot$ Łukasz Wolko $^{2} \cdot$ Artur Szwengiel $^{3} \cdot$ Anna Grygier $^{3} \cdot$ Katarzyna Nuc $^{2}$. \\ Małgorzata Majcher ${ }^{3}$
}

Received: 20 January 2021 / Revised: 20 April 2021 / Accepted: 7 May 2021 / Published online: 14 May 2021

(C) The Author(s) 2021

\begin{abstract}
The present study aimed to elucidate the effect of subinhibitory concentrations (sub-MICs) of juniper essential oil (EO), $\alpha$ pinene, and sabinene on the quorum-sensing (QS)-mediated proteolytic and lipolytic properties of Pseudomonas fluorescens KM24. These activities were verified under in situ conditions, in which sub-MICs of the agents altered the morphology of KM24 cells. RNA-Seq studies revealed key coding sequences (CDSs)/genes related to QS and the proteolytic/lipolytic activities of pseudomonads. In this work, all the examined agents decreased autoinducer synthesis and influenced the mRNA expression of the encoding acyltransferase genes $l p t A, l p t D$, and $p l s B$. The highest reduction on the $3^{\text {rd }}$ and $5^{\text {th }}$ days of cultivation was observed for the genes $\operatorname{lpt} D(-5.5$ and -5.61 , respectively) and $\operatorname{lpt} A$ ( -3.5 and -4.0 , respectively) following treatment with EO. Inhibition of the $l p t A, l p t D$, and $p l s B$ genes by singular constituents of EO was on average, from -0.4 to -0.7 . At 5 days of cultivation the profile of AHLs of the reference P. fluorescens KM24 strain consisted of 3-oxo-C14-HSL, 3-oxo-C6-HSL, C4-HSL, and $N$-[(RS)-3-hydroxybutyryl]-HSL, the concentrations of which were $0.570,0.018,3.744$, and $0.554 \mu \mathrm{g} \mathrm{ml}{ }^{-1}$, respectively. Independent of the incubation time, EO, $\alpha$-pinene, and sabinene also suppressed the protease genes prlC $(-1.5,-0.5$, and -0.5 , respectively) and $\operatorname{ctp} B(-1.5,-0.7$, and -0.4 , respectively). Lipolysis and transcription of the lipA/lipB genes were downregulated by the agents on average from -0.3 to -0.6 . $\alpha$-Pinene- and sabinene-rich juniper EO acts as an anti-quorumsensing agent and can repress the spoilage phenotype of pseudomonads.
\end{abstract}

\section{Key points:}

- Juniper EO, $\alpha$-pinene, sabinene exhibited anti-QS potential toward KM24.

- $\quad$ RNA-Seq revealed key CDSs/genes related to QS/proteolytic/lipolytic activities of KM24.

- Agents at sub-MIC levels influenced the mRNA expression of QS/lipase/protease genes.

Keywords Juniperus phoenicea L. essential oil · Quorum sensing · Pseudomonas fluorescens · Spoilage of seafood

Kamila Myszka

kamila.myszka@up.poznan.pl

1 Department of Biotechnology and Food Microbiology, Poznan University of Life Sciences, Wojska Polskiego 48, PL-60,627 Poznan, Poland

2 Department of Biochemistry and Biotechnology, Poznan University of Life Sciences, Dojazd 11, PL-60-632 Poznan, Poland

3 Department of Food Technology of Plant Origin, Poznan University of Life Sciences, Wojska Polskiego 31, PL-60-624 Poznan, Poland

\section{Introduction}

Spoilage of seafood during refrigerated storage is primarily due to autolysis, bacterial growth, and metabolic activities, which result in the formation of off-flavor compounds, and chemical oxidation of lipids. However, the synthesis of proteases and lipases by contaminated microflora is by far the most important factor decreasing seafood quality (Ackman 1994; Xie et al. 2018). Extracellular secreted proteases are free to degrade nitrogenous substrates, thereby leading to extensive damage to food constituents and the production of ammonia, trimethylamine, hydrogen sulfide, hexanal, and 2,4heptadienal (Haard 1994). Microbial lipases cause the 
production of off-flavor esters (Ackman 1994). All these factors lead to increased weight loss, reduced water-retention capacity, textural changes, and off-odor in fish-based products (Ackman 1994; Haard 1994). Approximately $10 \%$ of fishbased products are estimated to be lost each year as a result of microbial growth and proteolytic/lipolytic metabolism. Moreover, excessive spoilage of fish increases the overexploitation of natural resources to meet the global demand for fishbased products (Love et al. 2015).

Recent studies have shown that cold-tolerant Pseudomonas spp., mostly Pseudomonas fluorescens, can cause premature deterioration of seafood; these strains are dominant in sardine-, mackerel-, and salmon-based products under cold chain logistics (Venugopal 1990; Myszka et al. 2020). Spoilage activities of $P$. fluorescens within fish ecosystems may lead to the denaturation of muscle proteins, degradation of lipids, and structural damage to the fish membranes (Ackman 1994; Xie et al. 2018). Although pseudomonads are confirmed to decrease seafood quality, no systematic analysis of the spoilage activities of cold-tolerant $P$. fluorescens within food ecosystems has been performed to date. The mapping of molecular constituents in cells by high-throughput transcriptome sequencing technology (RNA-Seq) will contribute to our indepth understanding of $P$. fluorescens spoilage activities in fish-based products and indicate key coding sequences (CDSs)/genes with altered expression that lead to better inactivation of bacteria within food. This information may help to develop an effective strategy to combat spoilage microflora and/or verify the actual effect of novel/alternative biocides on $P$. fluorescens cells.

Our previous work revealed that pseudomonads under refrigeration conditions can synthesize autoinducers of quorumsensing (QS) systems (Myszka et al. 2020; Sobieszczańska et al. 2020). Autoinducers can interact with cognate receptor proteins, which leads to the expression of specific genes that regulate the spoilage activities of cells (Papenfort and Bassler 2016). Signal molecules of pseudomonads belong to the $N$ acyl-homoserine lactone (AHL) group; blockade of AHL synthesis can be regarded as a new preservation technique for fish-based products, potentially changing the expression level of genes related to the bacterial synthesis of lipases and proteases (Lee and Zhang 2015). Various chemicals for QS attenuation have been suggested, but only plant-derived essential oils (EOs) at subinhibitory concentrations (sub-MICs) meet the requirements of modern preservatives. Sub-MIC EOs can also be used as valuable flavoring and aromatizing seafood additives. The seafood to which EOs were added for flavoring purposes exhibits high microbial quality overall (Falleh et al. 2020). Recent reports have demonstrated that certain bioactive compounds from juniper EO are capable of repressing the synthesis of QS autoinducers; additionally, seasoning fish with juniper increases the sensory appeal of the products (Montagne 1999). However, it remains unclear how these agents influence the QS-modulatory properties of $P$. fluorescens within fish-based products.

This study aimed to elucidate the effect of sub-MICs of juniper EO and its major bioactive compounds on the QSmediated proteolytic and lipolytic activities of $P$. fluorescens KM24. This work verified the following hypotheses: (i) subMICs of juniper EO and its major constituents changed QS autoinducer production and (ii) sub-MICs of juniper EO and its major constituents downregulated the expression levels of genes encoding lipases and proteases, and therefore decreased the proteolytic and lipolytic activities of pseudomonads. In this study, the global $P$. fluorescens transcriptome was characterized for the first time, which indicated the expression of all the evaluated genes was related to AHL synthesis and the proteolytic/lipolytic activities of KM24 in situ. Scanning electron microscopy (SEM) observations were performed to evaluate the KM24 morphology under the influence of the tested antimicrobials.

\section{Materials and methods}

\section{Microorganisms}

The KM24 strain was isolated from commercially available fresh salmon (Salmo salar) fillets. Sequencing and analysis of restriction length polymorphisms of the 16S rRNA gene amplicon were carried out for strain identification. The strain was deposited at the Polish Collection of Microorganisms (WDCM 106) (Wroclaw, Poland) under the number PCM3107.

Chromobacterium violaceum CV026 (from the National Collection of Type Cultures, Salisbury, UK) was used as a biosensor strain to measure the level of AHL production by KM24. CV026 is a violacein and AHL-negative double miniTn5 mutant of the ATCC 31532 strain.

Cryovials (Medical Wire and Equipment, Corsham, UK) were used for the preservation of strains.

\section{In situ cultivation}

A fish juice medium obtained from fresh salmon fillets according to our previous work (Sobieszczańska et al. 2020) was developed for cultivation purposes. The medium was enriched with $0.10 \mathrm{M}$ phosphate buffer, $0.065 \mathrm{M} \mathrm{H}_{2} \mathrm{KPO}_{4}$, and $0.044 \mathrm{M} \mathrm{HK}_{2} \mathrm{PO}_{4}$ (POCH, Gliwice, Poland). The $\mathrm{pH}$ value of the medium was adjusted to 6.6. After sterilization, the medium was supplemented with $1.6 \mathrm{~g} / \mathrm{L}$ trimethylamine $\mathrm{N}$-oxide, $40 \mathrm{mg} / \mathrm{L} \mathrm{L}$-cysteine, and $40 \mathrm{mg} / \mathrm{L} \mathrm{L}$-methionine (Sigma-Aldrich, Merck KGaA, Saint Louis, USA).

Total lipid extraction in the fish juice medium was performed according to the modified Cvrtila et al. (2004) method. Briefly, $50 \mathrm{ml}$ of the medium was placed in a $300-\mathrm{ml}$ 
Erlenmeyer flask; then, $15 \mathrm{ml} \mathrm{HCl}$ (Sigma-Aldrich, Merck KGaA, Saint Louis, USA) was accurately pipetted into the flask, and the flask was connected to a reflux condenser. The mixture was boiled for $15 \mathrm{~min}$. Then, $10 \mathrm{ml}$ anhydrous ethanol (POCH, Gliwice, Poland) and $50 \mathrm{ml}$ petroleum ether (Sigma-Aldrich, Merck KGaA, Saint Louis, USA) were added. The content of the flask was shaken and allowed to settle, after which $15 \mathrm{ml}$ was pipetted off, passed through a cotton-wool guard plug, and filtered into a tared receiver. The sample was boiled in a water bath and then dried at $105^{\circ} \mathrm{C}$. The sample was reweighed.

The Bradford assay was used for estimation of protein in the fresh juice medium (Bradford 1976). A standard curve was generated for bovine serum albumin (Sigma-Aldrich, Merck KGaA, Saint Louis, USA), and the absorbance at $595 \mathrm{~nm}$ was read.

Fish juice media supplemented with selected concentrations of juniper $\mathrm{EO}$ and its major bioactive compounds were inoculated with $\mathrm{KM} 24$. The cultivation processes were carried out at $4{ }^{\circ} \mathrm{C} \pm 2{ }^{\circ} \mathrm{C}$ for 5 days.

\section{Whole-transcriptomic analysis (RNA-Seq) of KM24}

Total RNA from KM24 cells after 5 days of cultivation was isolated using an RNAqueous Kit (Thermo Fisher Scientific, Waltham, MA, USA) following the manufacturer's instructions. Excess ribosomal RNA was removed from the samples using a Ribominus Transcriptome Isolation Kit (Invitrogen, Carlsbad, CA, USA). Libraries were constructed using the Collibri $^{\mathrm{TM}}$ Stranded RNA Library Prep Kit from Illumina ${ }^{\mathrm{TM}}$ and the Collibri ${ }^{\mathrm{TM}} \mathrm{H} / \mathrm{M} / \mathrm{R}$ rRNA Depletion Kit (Invitrogen, Carlsbad, CA, USA). Before sequencing, the libraries were quantitatively and qualitatively assessed using a Qubit fluorimeter (Thermo Fisher Scientific, Waltham, MA, USA) and a Bioanalyzer DNA electropherogram (Agilent, Santa Clara, CA, USA). Next-generation sequencing (NGS) was conducted with a MiSeq Illumina sequencer using the MiSeq Reagent Kit v3 (150 cycles) (Illumina, Hayward, CA, USA). The sequence reads were processed using CLC Genomic Workbench v20 (Qiagen, Valencia, CA, USA). The reads were mapped to the appropriate reference bacterial genome (NZ_CP049044) with gene and CDS and Pfam annotations. The results were normalized by counting the fragments per kilobase million (FPKM) values. RNA-Seq data were deposited in the SRA NCBI data repository (Bioproject: PRJNA509367; Biosample: SRX9799403; SRA: SRR1337604).

\section{Juniper essential oil extraction and identification of compounds}

Juniper EO was extracted from dried berries of juniper (Juniperus phoenicea L.) from Italy by the hydrodistillation method in a Clevenger-type apparatus. Chemical characterization of juniper EO was further carried out by a HewlettPackard HP 7890A gas chromatograph coupled to a 5975C mass spectrometer (Agilent, Santa Clara, CA, USA) according to our previous study (Myszka et al. 2020). Mass spectra were obtained at $70 \mathrm{eV}$ in the mass scanning range of 33-350 $\mathrm{m} / \mathrm{z}$. Compounds of juniper EO were identified by comparing the mass spectra and peak retention indices (RIs) with those of standards of homologous series of $n$-alkanes (C7-C24) under the same operating conditions. The relative percentages of the specific compounds were determined based on the gas chromatography peak areas relative to the total EO.

\section{Sub-MIC determination}

The sub-MICs of juniper EO and major compounds against KM24 were evaluated using a broth macrodilution method according to the Clinical and Laboratory Standards Institute (2012). Juniper EO and its major compounds were diluted in dimethyl sulfoxide (DMSO) (Sigma-Aldrich, Merck KGaA, Saint Louis, USA) to obtain a range of concentrations. Uninoculated fish juice medium without juniper EO, $\alpha$-pinene, and sabinene (Sigma-Aldrich, Merck KGaA, Saint Louis, USA) served as the controls. Microbial growth was assessed during incubation at $4{ }^{\circ} \mathrm{C}$. The concentrations resulting in no significant growth inhibition were selected as sub-MICs.

\section{Morphology analysis of KM24}

The morphology of KM24 after treatment with sub-MICs of juniper EO, $\alpha$-pinene, and sabinene (Sigma-Aldrich, Merck KGaA, Saint Louis, USA) was evaluated by SEM (SU3500 Hitachi High-Technologies Corporation, Tokyo, Japan). After 5 days of cultivation, one drop of KM24 culture was deposited on a carbon sticker, air-dried, and coated with gold. For observations of samples, a low voltage $(15 \mathrm{kV})$ was used.

\section{Extraction and quantification/qualification of AHLs}

The method of Ravn et al. (2001) was used to extract QS autoinducers synthesized by KM24 in media supplemented with sub-MIC concentrations of juniper EO, $\alpha$-pinene, and sabinene (Sigma-Aldrich, Merck KGaA, Saint Louis, USA). Briefly, cultures were centrifuged ( $3000 \mathrm{~g}$ for $10 \mathrm{~min}$ ), and the supernatants were filtered through a Millex-GP $0.22-\mu \mathrm{m}$ filter (Sigma-Aldrich, Merck KGaA, Saint Louis, USA). The supernatants were extracted with ethyl acetate $(\mathrm{POCH}$, Gliwice, Poland), and the extracts were concentrated by rotary evaporation.

The method described by Blosser and Gray (2000) was used for rapid screening of the synthesis of AHLs by KM24. CV026 was grown overnight in TYB medium (BD, New 
Jersey, USA) and diluted in sterile medium to an optical density $(540 \mathrm{~nm})$ of 0.2 . Extracts of AHLs were redissolved in $1 \mathrm{ml}$ of the CV026 culture suspension. Samples were then incubated at $30{ }^{\circ} \mathrm{C}$ for $16 \mathrm{~h}$. Next, the cells were lysed by adding $200 \mu \mathrm{l}$ of $0.34 \mathrm{M}$ sodium dodecyl sulfate (SigmaAldrich, Merck KGaA, Saint Louis, USA), vortexing, and incubating at room temperature for $5 \mathrm{~min}$. Violacein was quantitatively extracted from the cell lysate by adding $900 \mu \mathrm{l}$ of butanol (Sigma-Aldrich, Merck KGaA, Saint Louis, USA). The absorbance of the butanol phase was read at $585 \mathrm{~nm}$ on a SPECORD ${ }^{2} 205$ UV-VIS spectrophotometer (Analytic Jena AG, Jena, Germany). The CV026 cell response of the AHL extract was calculated according to formula (1):

CVO26 responce of $A H L=(A / B) \times 1000$

where $A$ is the absorbance of the butanol extract of violacein and $B$ is the CV026 cell density.

The values obtained from the calculations are referred to as violacein units (UVs).

AHL molecules were also identified by a Dionex UltiMate 3000 (Thermo Fisher Scientific, Waltham, MA, USA) RPUHPLC chromatograph coupled with ESI-MS with a qTOF system using a Kinetex ${ }^{\mathrm{TM}} 1.7 \mathrm{Mm} \mathrm{C} 18100 \AA$ LC column with dimensions of $100 \times 2.1 \mathrm{~mm}$ (Phenomenex, Torrance, USA) according to our previous study (Myszka et al. 2020). Mass spectra were recorded in a scan range of $m / z 80-1200$. Data Analysis 4.1 software (Bruker Daltonik, Bremen, Germany) was used for LC-MS data processing. The molecular ions $[\mathrm{M}+\mathrm{H}]^{+}$and sodium adducts $[\mathrm{M}+\mathrm{Na}]^{+}$in positive ion mode were extracted from full-scan chromatograms. AHL molecules were identified by comparing the retention times of the samples with those of standards based on molecular mass information from the MS detector and MSMS data. Quantitative analyses of AHLs were conducted with calibration samples prepared in methanol as a surrogate matrix. The limits of detection (LODs) $(\mathrm{S} / \mathrm{N}<3)$ for the evaluated molecules were as follows: $0.04 \mu \mathrm{g} \mathrm{ml}^{-1}$ for C4-HSL and $N$-[(RS) - 3-hydroxybutyryl]-HSL and $0.005 \mu \mathrm{g} \mathrm{ml}^{-1}$ for 3-oxo-C14HSL.

\section{Proteolytic and lipolytic activity estimation}

The method proposed by Polychroniadou (1988) was used for estimation of KM24 proteolytic activity after treatment with sub-MICs of juniper EO, $\alpha$-pinene, and sabinene (SigmaAldrich, Merck KGaA, Saint Louis, USA) with some modifications. Briefly, $0.5 \mathrm{ml}$ of a pseudomonad culture was mixed with $0.5 \mathrm{ml}$ of buffer consisting of $0.1 \mathrm{M} \mathrm{Na}_{2} \mathrm{~B}_{4} \mathrm{O}_{7}$ in $0.1 \mathrm{M}$ $\mathrm{NaOH}$ (POCH, Gliwice, Poland). Next, $1 \mathrm{ml}(1 \mathrm{mg} / \mathrm{ml})$ of 2,4,6-trinitrobenzenesulfonic acid (TNBS) (Sigma-Aldrich, Merck KGaA, Saint Louis, USA) was added. After incubation of the samples at $37{ }^{\circ} \mathrm{C}$ for $60 \mathrm{~min}, 2 \mathrm{ml}$ of $0.1 \mathrm{M} \mathrm{NaH}_{2} \mathrm{PO}_{4}$
(POCH, Gliwice, Poland) containing $1.5 \mathrm{ml} \mathrm{Na}_{2} \mathrm{SO}_{3}$ (POCH, Gliwice, Poland) was added. The samples prepared with $0.5 \mathrm{ml}$ of $\mathrm{H}_{2} \mathrm{O}$ served as controls. The absorbance at $420 \mathrm{~nm}$ on a SPECORD ${ }^{\circledR} 205$ UV-VIS spectrophotometer (Analytic Jena AG, Jena, Germany) was read. The percentage of proteolytic activity inhibition was calculated according to the following formula (2):

Proteolytic activity inhibition $=100-(C / D \times 100)$

where $C$ is the absorbance value obtained for KM24 cultured on fish juice medium supplemented with sub-MICs of juniper $\mathrm{EO}$ and its major compounds and $D$ is the absorbance value obtained for KM24 cultured on fish juice medium.

For the quantitative determination of the lipolytic activity of KM24, a modified method of Stuer et al. (1986) was used. Briefly, $10 \mathrm{ml}$ of isopropanol containing $30 \mathrm{mg}$ of $p$-nitrophenyl phosphate ( $p$-NPP) (Sigma-Aldrich, Merck KGaA, Saint Louis, USA) was mixed with $90 \mathrm{ml}$ of $0.05 \mathrm{M}$ Sörensen phosphate buffer (Sigma-Aldrich, Merck KGaA, Saint Louis, USA), pH 8.0. The freshly prepared substrate solution $(2.4 \mathrm{ml})$ was prewarmed at $37^{\circ} \mathrm{C}$ and then mixed with $0.1 \mathrm{ml}$ of the supernatant of the KM24 culture. After 15 min of incubation at $37^{\circ} \mathrm{C}$, the absorbance at $420 \mathrm{~nm}$ on a SPECORD ${ }^{\circledR} 205$ UV-VIS spectrophotometer (Analytic Jena, AG, Jena, Germany) was read. The samples prepared with $0.1 \mathrm{ml}$ of $\mathrm{H}_{2} \mathrm{O}$ served as controls. The percentage of lipolytic activity inhibition was calculated according to the following formula (3):

Lipolytic activity inhibition $=100-(E / F \times 100)$

where $E$ is the absorbance value obtained for KM24 cultured on fish juice medium supplemented with sub-MICs of juniper EO and its major compounds and $F$ is the absorbance value obtained for KM24 cultured on fish juice medium.

\section{RNA isolation, cDNA synthesis and RT-qPCR}

The KM24 cultures were treated with RNAprotect ${ }^{\circledR}$ Bacteria Reagent (Qiagen, Valencia, CA, USA). A PureLink ${ }^{\mathrm{TM}}$ RNA Mini Kit (Thermo Fisher Scientific, Waltham, MA, USA) and a PureLink ${ }^{\mathrm{TM}}$ DNase Set (Invitrogen, Carlsbad, CA, USA) were used for total RNA isolation and purification. The quantity and quality of isolated RNA were estimated by the fluorescence-based Qubit ${ }^{\mathrm{TM}}$ XR RNA and Qubit ${ }^{\mathrm{TM}}$ IQ RNA Assay Kits (Thermo Fisher Scientific, Waltham, MA, USA) using a Qubit Fluorometer 4 (Thermo Fisher Scientific, Waltham, MA, USA). Total RNA $(1.0 \mu \mathrm{g})$ and a High Capacity RNA-to-cDNA Kit (Life Technologies, Carlsbad, USA) were used to synthesize first strand +cDNA.

RT-qPCR analyses were carried out in a CFX96 Touch Real-Time PCR Detection System (BioRad, Hercules, CA, USA) using GoTaq ${ }^{\circledR}$ Master Mix (Promega, Walldorf, Germany). The primers used in this work are listed in 
Table 1 The oligonucleotides applied in the RT-qPCR experiments

\begin{tabular}{lll}
\hline Primer & Sequence $\left(5^{\prime} \rightarrow 3^{\prime}\right)$ & Amplified region \\
\hline 16S_F & GGAGACTGCCGGTGACAAAC & 16S rRNA gene (universal primers) \\
16S_R & TGTAGCCCAGGCCGTAAGG & lptA gene \\
LPTA_F & ACCTGGCTTACTTCGAAC & \\
LPTA_R & ATGATGCGATTCTGCTGG & lptB gene \\
LPTB_F & CACCGTCATTTGAACACC & \\
LPTB_R & CCTTGTCCAGCCAGTATT & plsB gene \\
PLSB_F & GTTCTTCTACCTCACGCC & lipA gene \\
PLSB_R & ATTTGTGCATTCTCTTCGG & lipB gene \\
LIPA_F & CGAACTGCCGAAAAAACC & \\
LIPA_R & CTGTGCAGCTTGTGTTTG & prlC gene \\
LIPB_F & TGGTAAGCCGTATGGAGG & \\
LIPB_R & CCGAGTGAGGCGATTTTC & ctpB gene \\
PRLC_F & AAAGCCAGGGCAAAAATC & \\
PRLC_R & GTTACATACGGCGTTGAG & \\
CTPB_F & CAGAAAATCACCCTGACC & \\
CTPB_R & CTCTTCACGCTTTTGACC & \\
\hline
\end{tabular}

Table 1. In the RT-qPCR experiments, the $16 \mathrm{~S}$ rRNA gene was used as a reference gene. The following cycle conditions were applied: initial denaturation at $95{ }^{\circ} \mathrm{C}$ for 2 min and 45 cycles of denaturation at $95{ }^{\circ} \mathrm{C}$ for $15 \mathrm{~s}$ and annealing and extension at $58{ }^{\circ} \mathrm{C}$ for $1 \mathrm{~min}$. The effect of sub-MIC concentrations of juniper EO, $\alpha$-pinene, and sabinene on the changes in the expression of genes encoding QS autoinducer synthases, proteinases, and lipases in KM24 were calculated following the $2^{-\Delta \Delta \mathrm{Ct}}$ method (Schmittgen and Livak 2008).

\section{Statistical analysis}

Experiments were performed in triplicate. The results are presented as the means \pm standard deviations. To characterize the difference between specific results, Tukey's parametric post hoc test in Statistica software was used (Statsoft, Inc., 2012). Statistical significance was considered at $p<0.05$.

\section{Results}

\section{Protein and lipid contents in fish juice medium}

To characterize the model growth environment for saprotrophic KM24, the contents of total protein and lipids were determined. The protein level of the examined medium was $1.8 \mathrm{mg} \mathrm{g}^{-1}$; the lipid content expressed on a wet weight basis was $0.635 \mathrm{mg} \mathrm{g}^{-1}$.

\section{RNA-Seq data processing and pfam analysis of differentially expressed CDSs/genes}

In this work, the sequencing efficiency was $554.85 \mathrm{Mbp}$, and the cluster density was $97 \mathrm{~K} \mathrm{~mm}^{-2}$. The $Q$ score value, which indicates the quality of the sequencing performed for $90.87 \%$ of the bases read, was 30 . The percentage of passes filtered (PFs) for sequencing was $80.13 \%$. Among $92.65 \%$ of the mapped readings, 91.38\% were paired (Supplemental Table S1; Supplemental Fig. S1). The distribution of the distances between the ends of paired readings ranged from 50 to $150 \mathrm{bp}$. The number of CDS to which the readings were mapped was $1850 ; 1750$ genes/CDSs were differentially expressed in KM24 cells incubated in fish juice medium. The reference sequences were prepared by an overlay with gene/CDS annotations using the Find Prokaryotic Genes tool. The conserved domains, gene names and functions of particular reading frames were assigned by the Annotate CDS with the Pfam Domains tool.

The transcribed/mapped genes/CDSs were screened with the criteria of the cellular/metabolic process category mainly associated with the QS system and the QS-mediated proteolytic and lipolytic activities of pseudomonads. The characteristics of the selected CDS of the pseudomonads transcriptome are presented in Table 2.

Three of the mapped genes/CDSs were matched to the QS system: lptA, lptD, and $p l s B$. These genes/CDSs encode acyltransferases that affect QS autoinducers. The FPKM value of $l p t A, l p t D$, and $p l s B$ was respectively: 47.0, 10.77, and 6.75, respectively. Two of the subsequently identified CDS, namely, $p r l C$ and $\operatorname{ctp} B$, encode peptidases and lipA and lipB encode lipases in pseudomonads under in situ conditions. The FPKM values of $p r l C$ and $c t p B$ were 23.0823 .12 , respectively. The FPKM values of lipA and lipB were 23.38 and 26.11, respectively (Table 2).

\section{Chemical composition of juniper EO}

The results of the GC/MS analysis described the chemical composition of juniper EO, and the relative percentages of 
Table 2 The characteristics of the selected CDSs of Pseudomonas fluorescens transcriptome. Reference genome no. LS483372

\begin{tabular}{|c|c|c|c|c|}
\hline Name & Region & $\begin{array}{l}\text { Fragment per kilobase } \\
\text { million value }\end{array}$ & $\begin{array}{l}\text { Gene } \\
\text { length }\end{array}$ & Description \\
\hline lptA & $1179239 . .1179814$ & 47.00 & 576 & $\begin{array}{l}\text { Acyltransferase affect } \\
\text { quorum-sensing signaling }\end{array}$ \\
\hline $\operatorname{lpt} D$ & $5869389 . .5872214$ & 10.77 & 2826 & $\begin{array}{l}\text { Acyltransferase affect } \\
\text { quorum-sensing signaling }\end{array}$ \\
\hline pls $B$ & $1553874 . .1556378$ & 6.75 & 2505 & $\begin{array}{l}\text { Acyltransferase affect } \\
\text { quorum-sensing signaling }\end{array}$ \\
\hline $\operatorname{prlC}$ & $52930 . .54981$ & 23.08 & 2052 & Metalloprotease \\
\hline$c t p B$ & $424112 . .425428$ & 23.12 & 1317 & Protease \\
\hline lipA & $5678195 . .5679220$ & 23.38 & 1026 & Lipase \\
\hline $\operatorname{lip} B$ & $5679223 . .5679870$ & 26.11 & 648 & Lipase \\
\hline
\end{tabular}

22 identified compounds are presented in Table 3. A TIC chromatogram of $J$. phoenicea L. EO on DB-5 column was presented on Supplemental Fig. S2. The major compounds comprising $>8.0 \%$ of the total juniper EO volume were $\alpha$ pinene $(48.3 \%)$ and sabinene $(8.4 \%)$. $\beta$-Pinene, $\alpha$ terpinolene, and terpinen-4-ol were detected in minor amounts, ranging from 5.2 to $4.0 \%$ of juniper EO. The

Table 3 Essential oil composition (\%) of Juniperus communis

\begin{tabular}{lccc}
\hline Compound & RI - Wax & RI - DB-5 & Yield percentage (n-3) \\
\hline$\alpha$-Thujene & 1021 & 938 & 0.8 \\
$\alpha$-Pinene & 1035 & 939 & 48.3 \\
Camphene & 1080 & 953 & 3.5 \\
$\beta$-Pinene & 1118 & 980 & 5.2 \\
Sabinene & 1125 & 974 & 8.4 \\
$\beta$-Myrcene & 1158 & 990 & 3.4 \\
$\alpha$-Phellandrene & 1170 & 1006 & 1.5 \\
Limonene & 1208 & 1030 & 1.6 \\
$\beta$-Phellandrene & 1245 & 1042 & 1.5 \\
$\gamma$-Terpinene & 1249 & 1072 & 1.5 \\
$p$-Cymene & 1274 & 1026 & 1.1 \\
$\alpha$-Erpinolene & 1279 & 1083 & 4.0 \\
Borneol & 1506 & 1156 & 1.1 \\
Linalol & 1544 & 1100 & 0.9 \\
Bornyl acetate & 1584 & 1277 & 0.8 \\
$\beta$-Caryophyllene & 1594 & 1414 & 2.4 \\
Terpinen-4-ol & 1606 & 1180 & 4.5 \\
$\alpha$-Caryophyllene & 1668 & 1449 & 2.8 \\
$\alpha$-Terpineol & 1700 & 1192 & 1.5 \\
Germacrene & 1705 & 1487 & 1.0 \\
Nerol & 1792 & 1230 & 1.4 \\
Geraniol & 1852 & 1266 & 2.8 \\
\hline
\end{tabular}

$\%$ Composition-the percentage composition calculated from the chromatogram obtained on the Supelcowax 10 column. Normalized peak area \%. RI-Wax, retention index on Suplecowax 10 column; $R I-D B-5$, retention index on DB-5 column remaining compounds occurred in trace amounts $(<4.0 \%)$. Individual juniper EO constituents categorized in the monoterpene group were dominant in the examined EO and accounted for $96.2 \%$ of the total volume; the presence of constituents of the sesquiterpene group did not exceed $3.8 \%$ of the total oil.

\section{Minimum inhibitory concentration determination}

To evaluate the antibacterial effect of selected dilutions of juniper EO, $\alpha$-pinene, and sabinene against KM24, the buildup of biomass was monitored. In this study, concentrations below the sub-MIC of juniper EO $\left(120 \mu \mathrm{ml}^{-1}\right), \alpha$-pinene $\left(40 \mu \mathrm{ml}^{-1}\right)$, and sabinene $\left(30 \mu \mathrm{ml}^{-1}\right)$ were used for further experiments.

\section{Effect of sub-MICs of juniper EO, a-pinene, and sabinene on KM24 morphology}

Microscopic comparison of KM24 reference cultures with KM24 cells treated with sub-MICs of juniper EO, $\alpha$-pinene, and sabinene revealed changes in the morphology of cells, as shown in Fig. 1. Changes in cell dimensions, mainly in length from 1.19 to $1.37 \mu \mathrm{m}$ for juniper EO, from 0.757 to $1.30 \mu \mathrm{m}$ for $\alpha$-pinene and from 0.684 to $1.46 \mu \mathrm{m}$ for sabinene, were found. In the control, the length of cells ranged from 1.29 to $1.54 \mu \mathrm{m}$. The surface of untreated KM24 cells was smooth, the morphology was regular with an intact cell membrane, and individual bacteria were readily distinguishable (see Fig. 1).

\section{Effect of sub-MICs of juniper EO, a-pinene, and sabinene on quorum-sensing autoinducer synthesis}

In this study, the pour plate method was first carried out to evaluate the antibacterial activity of sub-MICs of juniper EO, $\alpha$-pinene, and sabinene toward the biosensor CV026 strain. No viability limitations of the biosensor strain at the examined concentrations of the tested agents were observed; therefore, 
Fig. 1 Microscopic images of Pseudomonas fluorescens KM24 cells grown on fish juice medium (A) supplemented with juniper essential oil (B), $\alpha$-pinene (C), and sabinene (D) (magnification ranging from $\times 10000$ to $\times 14000$ )
A

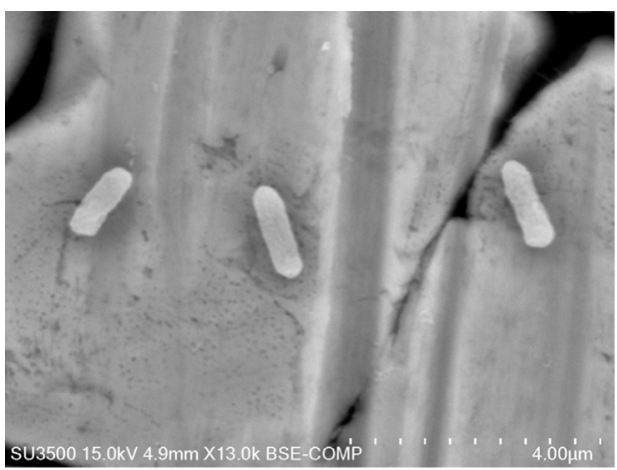

B

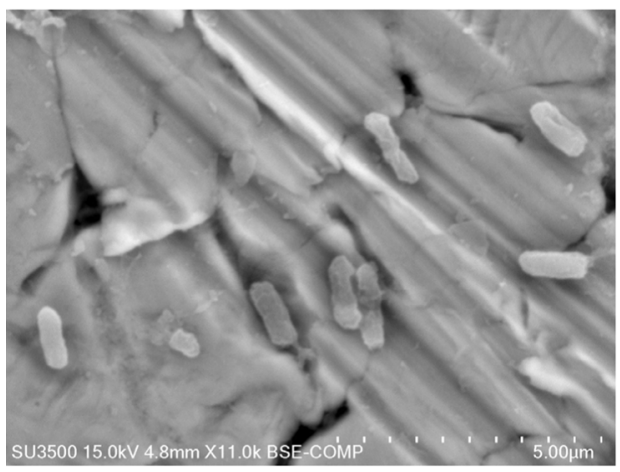

C

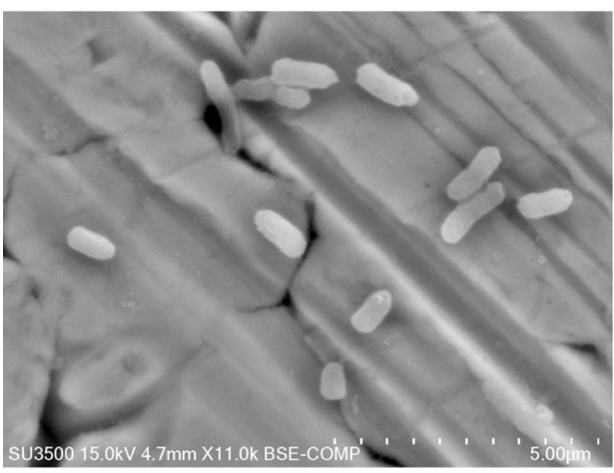

D

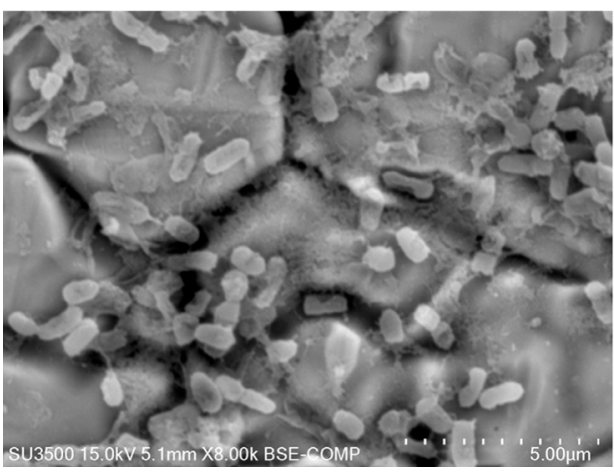

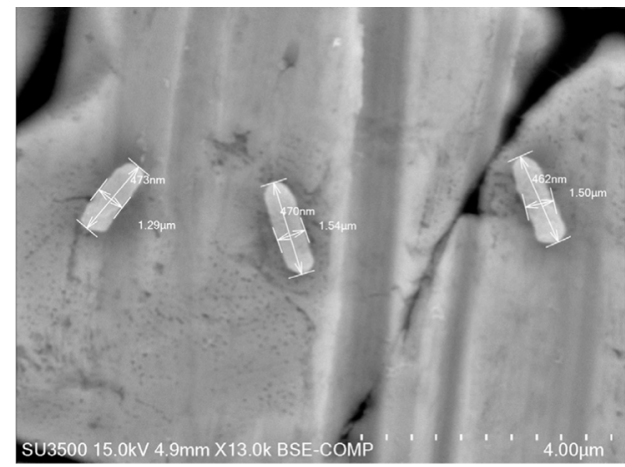
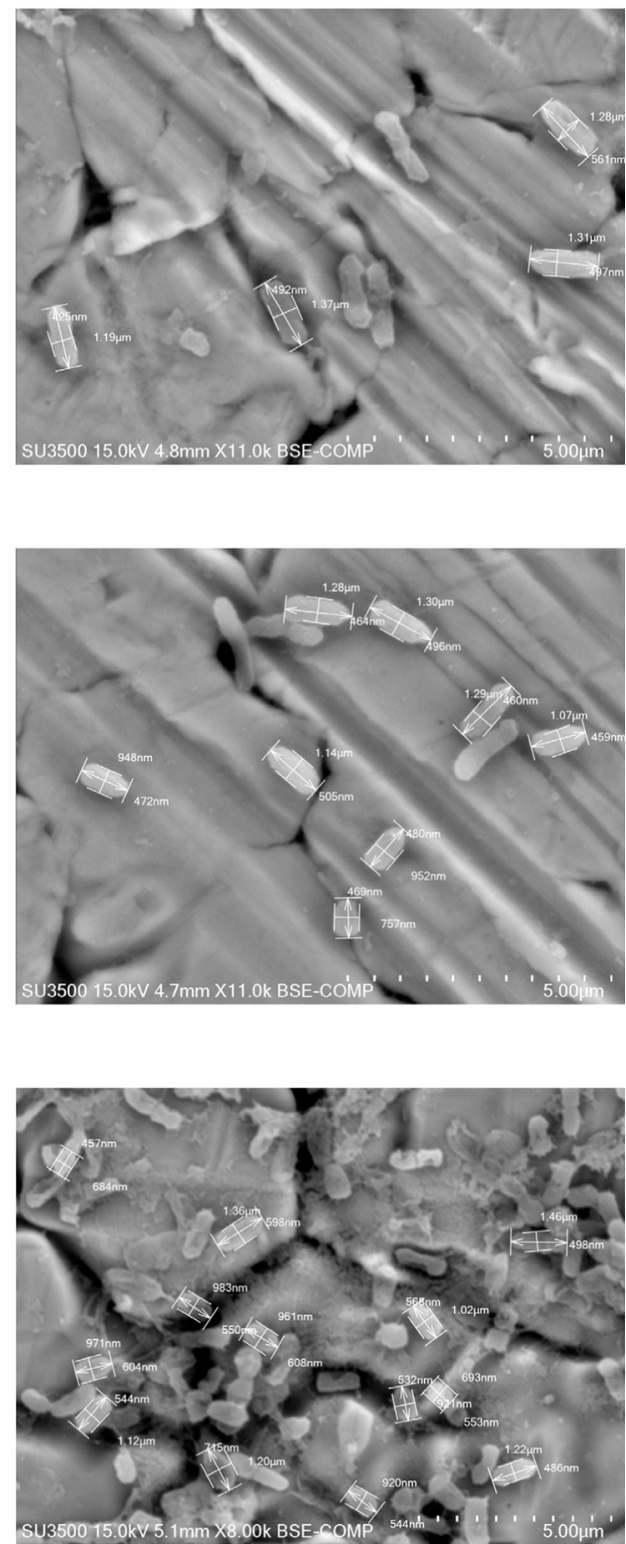

the CV026 strain can be used as a biomarker for the presence of AHL (Supplemental Table S2).
The Blosser and Gray (2000) assay was carried out to screen the anti-QS activity of juniper EO, $\alpha$-pinene, and 
sabinene. In the assay, the pigmentation (purple-colored violacein production) of CV026 provided a naturally occurring phenotype in response to the presence of AHL with $\mathrm{N}$ acyl side chains from $\mathrm{C} 4$ to $\mathrm{C} 8$ in length; limited AHL production by KM24 or low levels of AHL in fish juice medium inhibited violacein synthesis (Blosser and Gray 2000). Changes in AHL-related violacein production are shown in Fig. 2. The sub-MIC of juniper EO showed the highest antiQS activity; in these experiments, a reduction of $80 \%$ at 3 days and $95 \%$ at 5 days of incubation in AHL-mediated violacein synthesis was noticed. Sub-MICs of $\alpha$-pinene and sabinene caused reductions in violacein synthesis in the biosensor strain of approximately $75 \%$ and $70 \%$, respectively, at all stages of cultivation examined (Fig. 2).

For further verification of the anti-QS activity of juniper EO, $\alpha$-pinene, and sabinene at sub-MICs, the RP-UHPLCESI-MS system was used. The results of the experiments are presented in Table 4 and Supplemental Fig. S3. In the study, no evidence of QS autoinducers was found in samples collected from KM24 treated with all examined agents at all tested points. The profile of AHL of the reference KM24 culture at 5 days of cultivation consisted of 3-oxo-C14-HSL, 3-oxo-C6HSL, C4-HSL, and $N$-[(RS)-3-hydroxybutyryl]-HSL. The concentrations of these molecules were: $0.570,0.018,3.744$, and $0.554 \mu \mathrm{g} \mathrm{ml}^{-1}$, respectively. (see Table 4).

Next, RT-qPCR experiments were carried out to gain insight into the molecular mechanism of the anti-QS activity of juniper EO, $\alpha$-pinene, and sabinene at sub-MIC concentrations. In this work, mRNA expression of AHL synthase/ acyltransferase genes in the KM24 strain was evaluated. KM24 cultivated in fish juice medium served as reference probes. The transcriptional changes in the $l p t A, l p t D$, and $p l s B$ genes were calculated as relative quantities normalized to the 16S rRNA gene.

$J$. phoenicea L. EO influenced the mRNA expression of all genes (i.e., $l p t A, \operatorname{lpt} D$, and $p l s B$ ) encoding acyltransferases (see Table 5); however, the highest reduction on the $3^{\text {rd }}$ and $5^{\text {th }}$ days of cultivation was observed for the $l p t D(-5.5$ and -5.61 , respectively) and $\operatorname{lptA}(-3.5$ and -4.0 , respectively) genes. In this study, the application of sub-MICs of $\alpha$ pinene and sabinene to fish juice medium decreased the expression of QS autoinducer-related genes. The compounds downregulated all the genes evaluated at all the cultivation points, but the inhibition was only from -0.4 to -0.7 on average (Table 5).

\section{Effect of sub-MICs of juniper EO, a-pinene, and sabinene on KM24 proteolytic activity}

The changes in the proteolytic activity of KM24 caused by sub-MIC concentrations of juniper EO, $\alpha$-pinene, and sabinene were investigated by spectrophotometric analysis with the TBNS reagent. The results of the percentage of inhibition of proteolysis after exposure of cells to sub-MICs of juniper EO and its major compounds are presented in Fig. 3. In this work, all of the agents used decreased the proteolytic activity of KM24 considerably $(p<0.05)$. The highest reduction was observed for pseudomonads treated with juniper EO (42\%), while sabinene at sub-MIC concentrations had the lowest effect on the proteolytic activity of the bacteria examined (22\%) (Fig. 3).

To extend the results obtained from the spectrophotometric measurements, the effects of juniper EO, $\alpha$-pinene, and sabinene at sub-MICs on the expression of genes encoding proteases in KM24 were evaluated. As mentioned previously, the genes were indicated in the RNA-Seq experiment. In this work, the transcriptional levels of $\operatorname{prlC}$ and $\operatorname{ctp} B$ were normalized to the nondifferentially expressed reference 16S rRNA gene. As shown in Table 6, gene expression changed divergently; all the genes were downregulated by the applied treatments at all the examined time points. The highest reduction was observed for the $\mathrm{prlC}$ gene after treatment with sub-MICs of juniper EO. On the $3^{\text {rd }}$ and $5^{\text {th }}$ days of cultivation of the KM24 strain on fish juice medium supplemented with juniper
Fig. 2 Chromobacterium violaceum $\mathrm{CV} 026$ cell response to AHL extract obtained from Pseudomonas fluorescens KM24 grown on fish juice medium supplemented with juniper essential oil, $\alpha$-pinene, and sabinene. Also is shown is the significance of the experimental data determined by $t$-test $(p<$ $0.005)$. Bars indicate standard deviation from three experiments

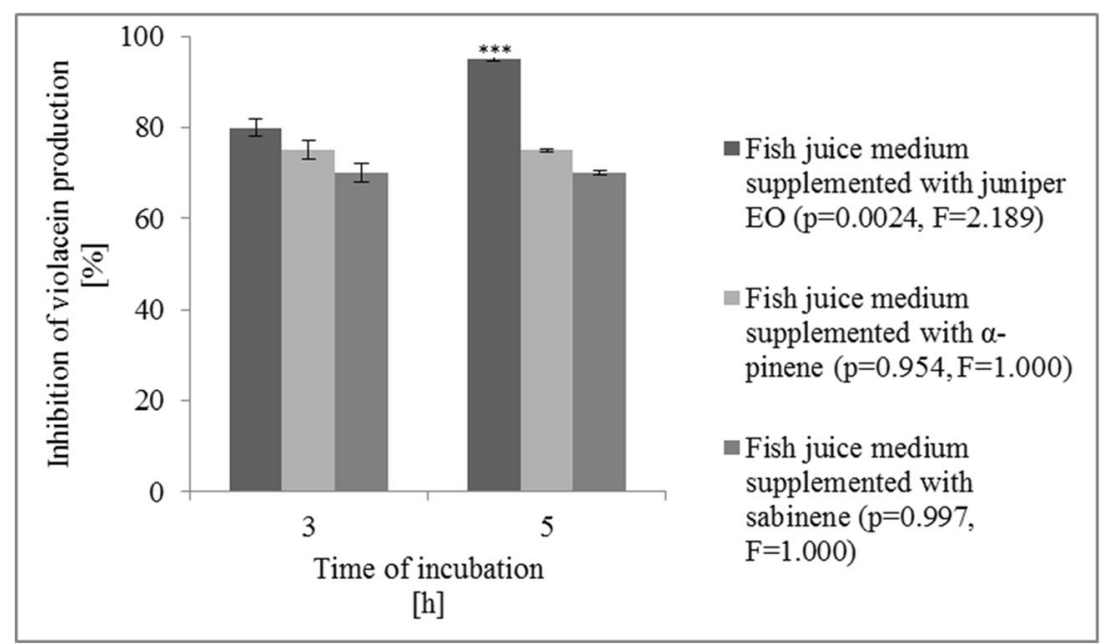


Table 4 RP-UHPLC-ESI-MS results of quality and quantity of quorum-sensing autoinducers produced by Pseudomonas fluorescens KM24 grown in fish juice medium enriched with juniper essential oil, $\alpha$-pinene, and sabinene

\begin{tabular}{|c|c|c|c|c|c|c|c|c|}
\hline \multirow{4}{*}{$\begin{array}{l}\text { Autoinducer } \\
\left(\mu \mathrm{g} \mathrm{ml}^{-1}\right)\end{array}$} & \multicolumn{8}{|c|}{ Growth conditions } \\
\hline & \multicolumn{2}{|c|}{ Fish juice medium } & \multicolumn{2}{|c|}{$\begin{array}{l}\text { Fish juice medium } \\
\text { supplemented with juniper } \\
\text { essential oil }\end{array}$} & \multicolumn{2}{|c|}{$\begin{array}{l}\text { Fish juice medium } \\
\text { supplemented with } \alpha \text { - } \\
\text { pinene }\end{array}$} & \multicolumn{2}{|c|}{$\begin{array}{l}\text { Fish juice medium } \\
\text { supplemented with } \\
\text { sabinene }\end{array}$} \\
\hline & \multicolumn{8}{|c|}{$\begin{array}{l}\text { Time of incubation } \\
\text { (days) }\end{array}$} \\
\hline & 3 & 5 & 3 & 5 & 3 & 5 & 3 & 5 \\
\hline 3-охо-C14-HSL & $<$ LOD $^{*}$ & $0.570 \pm 0.01$ & $<$ LOD $^{*}$ & $<$ LOD $^{*}$ & $<$ LOD $^{*}$ & $<\mathrm{LOD}^{*}$ & $<$ LOD $^{*}$ & $<$ LOD $^{*}$ \\
\hline 3-oxo-C6-HSL & $0.014 \pm 0.01$ & $0.018 \pm 0.0$ & $<$ LOD $^{*}$ & $<$ LOD $^{*}$ & $<\mathrm{LOD}^{*}$ & $<\mathrm{LOD}^{*}$ & $<$ LOD $^{*}$ & $<$ LOD $^{*}$ \\
\hline C4-HSL & $<$ LOD $^{*}$ & $3.744 \pm 0.15$ & $<$ LOD $^{*}$ & $<$ LOD $^{*}$ & $<\mathrm{LOD}^{*}$ & $<$ LOD $^{*}$ & $<$ LOD $^{*}$ & $<$ LOD $^{*}$ \\
\hline$N$-[(RS)-3-hydroxybutyryl]-HSL & $<\mathrm{LOD}^{*}$ & $0.554 \pm 0.01$ & $<\mathrm{LOD}^{*}$ & $<$ LOD $^{*}$ & $<\mathrm{LOD}^{*}$ & $<$ LOD $^{*}$ & $<$ LOD $^{*}$ & $<\mathrm{LOD}^{*}$ \\
\hline
\end{tabular}

$<$ LOD $^{*}$ - under the limit of detection

oil, the mRNA level of prlC decreased to -3.5 and -4.2 , respectively. $\alpha$-Pinene and sabinene were also downregulated by all the proteases, but the degrees of change only ranged from -0.4 to -1.0 .

\section{Effects of sub-MICs of juniper EO, a-pinene, and sabinene on KM24 lipolytic activity}

In this work, the spectrophotometric measurements employed by Stuer et al. (1986) and RT-qPCR experiments were performed to evaluate the effects of sub-MICs of juniper EO and its major compounds on the lipolytic activities of KM24. The addition of sub-MICs of juniper EO, $\alpha$-pinene, and sabinene to fish juice medium inhibited lipase synthesis. However, the highest reduction in lipase production was recorded for pseudomonads treated with the oil $(45 \%)$; $\alpha$-pinene and sabinene at sub-MIC levels decreased bacterial lipase production to $25 \%$ and $13 \%$, respectively (Fig. 4).

In this study, expression of the $\operatorname{lip} A$ and $\operatorname{lip} B$ genes confirmed the effect of the agents examined on the anti-lipolytic

Table 5 RT-qPCR confirmation of relative expression level of quorumsensing-related genes of Pseudomonas fluorescens KM24 grown in fish juice medium enriched with juniper essential oil, $\alpha$-pinene, and sabinene

\begin{tabular}{|c|c|c|c|}
\hline \multirow[t]{3}{*}{$\begin{array}{l}\text { Time of } \\
\text { incubation } \\
\text { (days) }\end{array}$} & $\begin{array}{l}\text { Fish juice medium } \\
\text { supplemented } \\
\text { with juniper EO }\end{array}$ & $\begin{array}{l}\text { Fish juice } \\
\text { medium } \\
\text { supplemented } \\
\text { with } \alpha \text {-pinene }\end{array}$ & $\begin{array}{l}\text { Fish juice } \\
\text { medium } \\
\text { supplemented } \\
\text { with sabinene }\end{array}$ \\
\hline & \multicolumn{3}{|c|}{$\log _{2}$ (relative quantity) } \\
\hline & lptA lptD & lptA lptD plsB & lptA lptD plsB \\
\hline 3 & $\begin{array}{lll}-3.5 & -5.5 & -1.5\end{array}$ & $\begin{array}{lll}-0.6 & -0.5 & -0.4\end{array}$ & $\begin{array}{lll}-0.4 & -0.5 & -0.6\end{array}$ \\
\hline 5 & $\begin{array}{lll}-4.0 & -5.61 & -1.8\end{array}$ & $\begin{array}{lll}-0.7 & -0.5 & -0.5\end{array}$ & $\begin{array}{lll}-0.5 & -0.5 & -0.6\end{array}$ \\
\hline
\end{tabular}

activities of KM24. Interestingly, regardless of the antimicrobial used, most gene expression was inhibited by between -0.4 and -0.6 on average (Table 7 ).

\section{Discussion}

Live fish harbor cold-tolerant Pseudomonas spp., which can thus be considered the primary source of spoilage organisms on processed products (Ghaly et al. 2010; Møretro et al. 2016). With an increasing number of reports of food spoilage incidents associated with cold-tolerant pseudomonads, solutions to prevent this phenomenon are urgently needed. $P$. fluorescens cultured at $4{ }^{\circ} \mathrm{C}$ exhibits higher spoilage potential than at the optimum temperature. The resistance traits of pseudomonads against conventional antimicrobials in food necessitate the search for alternative ways to manage bacterial metabolism and improve food quality and safety. Recently, the application of EOs has received much attention in the food industry due to their ecofriendliness, biodegradability, and mostly anti-QS properties (Tzortzakis and Economakis 2007). The stresses imposed by sub-MICs of EOs may interrupt autoinducer production and consequently downregulate QS-related enzymatic activity. However, the above hypothesis requires detailed verification under in situ conditions.

In this work, fish juice medium was used as a seafoodmimicking system to cultivate the wild-type KM24 strain. We determined the specific proportions of protein $(1.8 \mathrm{mg}$ $\left.\mathrm{g}^{-1}\right)$ and lipids $\left(0.635 \mathrm{mg} \mathrm{g}^{-1}\right)$ in the fish juice medium that did not differ from the average proportion of these components in marine salmon. The lipid content of marine salmon may vary between 0.58 and $7.83 \mathrm{mg} \mathrm{g}^{-1}$ (Zhang et al. 2020). The amount of protein in salmon muscle is usually somewhere between 1.5 and $2.0 \mathrm{mg} \mathrm{g}^{-1}$ (Tsuyuki et al. 1962). Fish juice 
Fig. 3 Inhibition of proteolytic activity of Pseudomonas fluorescens KM24 grown on fish juice medium supplemented with juniper essential oil, $\alpha$-pinene, and sabinene. $t$-test showed no significant difference between experimental data $(p<0.005)$. Bars indicate standard deviation from three experiments

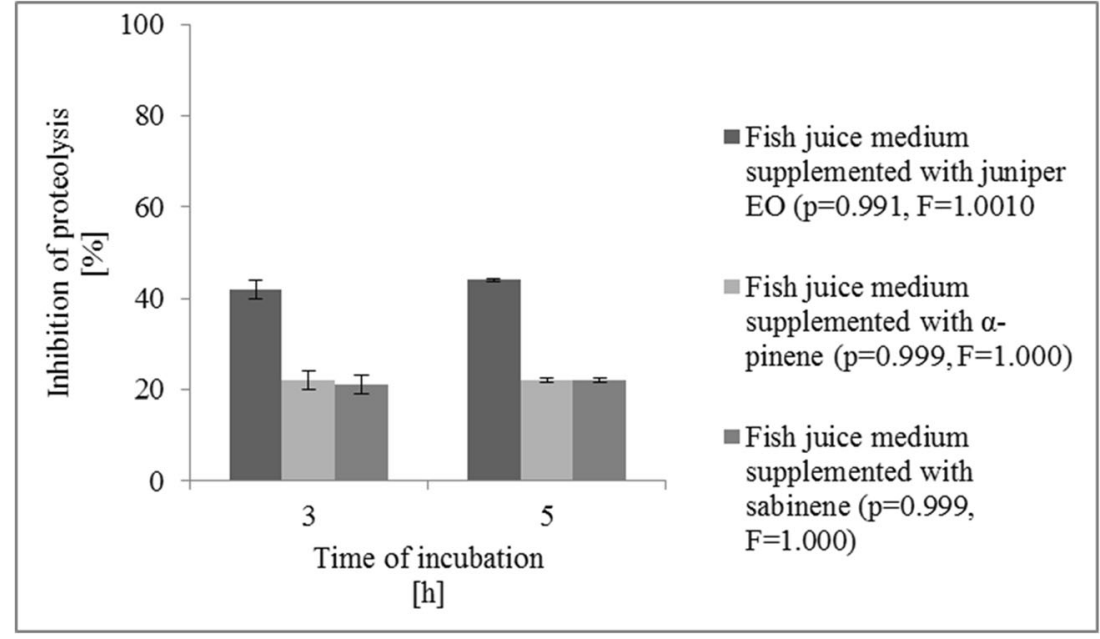

medium provides pseudomonads with the right amount of nutrients and can thus simulate seafood.

In this study, RNA-Seq analysis revealed the physiological responses of the KM24 strain to the seafood ecosystem. In this work, transcribed genes/CDSs related to the QS process and enzymatic activity of the KM24 strain were unambiguously selected. The information obtained from RNA-Seq guaranteed the appropriate design of the RT-qPCR experiments. In this work, RNA-Seq analysis indicated key genes that are disrupted by food preservatives and may ultimately improve the quality and safety of fish-based products.

RNA-Seq analysis revealed three transcribed genes (i.e., $l p t A, l p t D$, and $p l s B)$ that are annotated as acyltransferase genes associated with the QS mechanism. Acyltransferase is an enzyme that transfers acyl groups to a target molecule. QS autoinducers contain an acyl moiety on their side chain, and the acyl groups of AHLs are a determinant of the specificity of QS autoinducers; appropriate transfer of acyl groups might be important in AHL synthesis, and acyltransferases can affect the profile of AHL production and possibly modulate QS signaling of bacteria (Yeom et al. 2013). lptA, lptD, and plsB

Table 6 RT-qPCR confirmation of relative expression level of genes encoding proteases in Pseudomonas fluorescens KM24 grown in fish juice medium enriched with juniper essential oil, $\alpha$-pinene, and sabinene

\begin{tabular}{|c|c|c|c|c|c|c|}
\hline \multirow[t]{3}{*}{$\begin{array}{l}\text { Time of incubation } \\
\text { (days) }\end{array}$} & \multicolumn{2}{|c|}{$\begin{array}{l}\text { Fish juice } \\
\text { medium } \\
\text { supplemented } \\
\text { with juniper } \\
\text { EO }\end{array}$} & \multicolumn{2}{|c|}{$\begin{array}{l}\text { Fish juice } \\
\text { medium } \\
\text { supplemented } \\
\text { with } \alpha \text {-pinene }\end{array}$} & \multicolumn{2}{|c|}{$\begin{array}{l}\text { Fish juice } \\
\text { medium } \\
\text { supplemented } \\
\text { with sabinene }\end{array}$} \\
\hline & \multicolumn{6}{|c|}{$\log _{2}$ (relative quantity) } \\
\hline & $\operatorname{prlC}$ & $\operatorname{ctp} B$ & $\operatorname{prlC}$ & $\operatorname{ctp} B$ & prlC & $\operatorname{ctp} B$ \\
\hline 3 & -3.5 & -1.5 & -0.4 & -1.0 & -0.5 & -0.5 \\
\hline 5 & -4.2 & -1.5 & -0.5 & -1.0 & -0.5 & -0.6 \\
\hline
\end{tabular}

encode a lysophatidic acid acyltransferase that catalyzes the second step of the biosynthetic pathway of phospholipids, which has been recognized to affect QS autoinducer production (Baysse et al. 2005). Baysse et al. (2005) revealed that a lptA mutation resulted in premature production of AHLs (mostly C4-HSL and C6-HSL) and repression of autoinducer synthesis at the stationary growth phase. The relationship between acyltransferase and QS was also reported in the study by Laue et al. (2000), where the acyltransferase of $P$. fluorescens F113 directly synthesizes AHLs. Additionally, the results of Yeom et al. (2013) suggest that acyltransferases play an important role in the QS regulation and expression of virulence factors.

In this work, systematic analysis of the RNA-Seq results also revealed two transcribed genes (namely, $p r l C$ and $c t p B$ ) involved in pseudomonads proteolysis in fish juice medium. prlC is involved in hydrolysis of oligopeptides that accumulate in large amounts in fish muscle (Venugopal 1990). The $c t p B$ encodes an exoprotease that cleaves the fish protein substrate at the carboxyl terminus (Venugopal 1990). Secretion of both oligopeptidase A and exoprotease results in fish spoilage, which leads to the accumulation of volatile basic nitrogen compounds (Xie et al. 2018).

In this study, the global transcription profile of pseudomonads was also screened for genes/CDSs encoding lipases. Pseudomonas spp. lipases display thermoresistance and activity at alkaline $\mathrm{pH}$. These traits are not common among lipases produced by other microorganisms, which highlights the importance of pseudomonad lipolytic activity in the seafood spoilage process (Martínez and Soberón-Chávez 2001). Similar to Dieckelmann et al. (1998), who investigated the diversity of lipases from psychrotrophic P. fluorescens C9, two transcribed genes, namely, $\operatorname{lip} A$ and $\operatorname{lip} B$, which encode lipases, were detected in KM24 incubated in fish juice medium. The lipase encoded by lipB is solely responsible for the "lipolytic phenotype" of $P$. fluorescens, which leads to rancidity, a soapy off-flavor, and other quality defects of fish- 
Fig. 4 Inhibition of lipolytic activity of Pseudomonas fluorescens KM24 grown on fish juice medium supplemented with juniper essential oil, $\alpha$-pinene, and sabinene. $t$-test showed no significant difference between experimental data $(p<0.005)$. Bars indicate standard deviation from three experiments

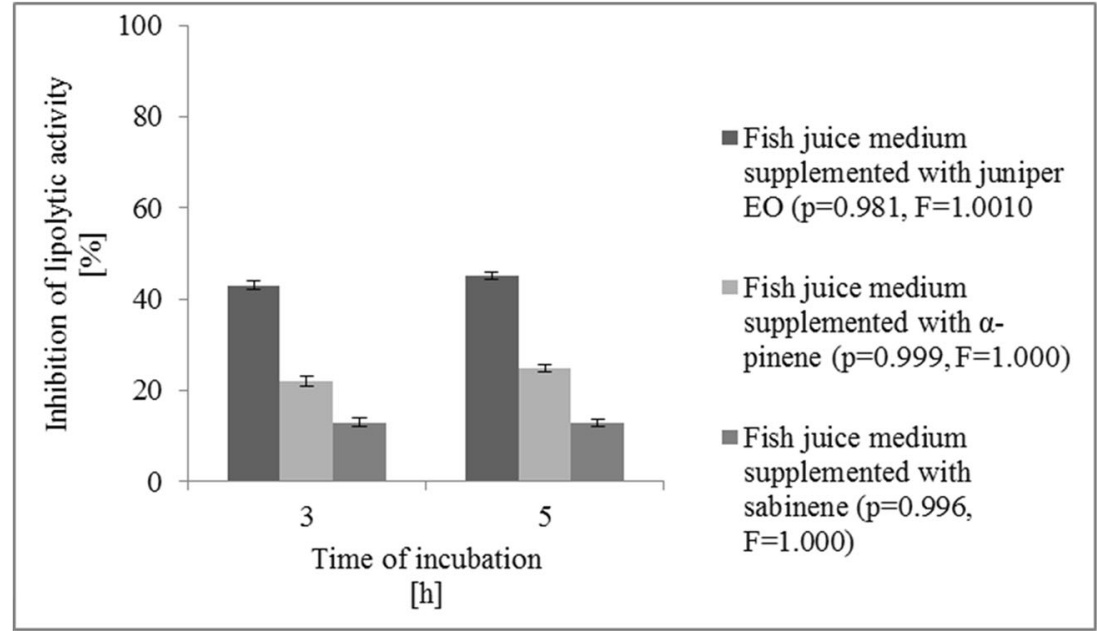

based products (Beven et al. 2001). lipA is located at the end of a polycistronic operon in the apr gene cluster; its absence results in the loss of or relatively low lipolytic activities of Pseudomonas spp. (Woods et al. 2001).

Based on the work of Kerekes et al. (2013), EO from Juniperus phoenicea L. berries was used as an anti-QS agent toward KM24. In food industry systems, this oil reduces the formation of QS-related biofilms of foodborne Bacillus cereus, Escherichia coli, and Campylobacter jejuni (Kerekes et al. 2013; Šimunović et al. 2020). Moreover, fish-based products can be seasoned with juniper berries, through which seafood products obtain the taste desired by consumers (Montagne 1999).

In this study, the volatile constituents of juniper EO were determined by GC/MS analysis. Similar to the results of Höferl et al. (2014), high levels of representatives of the monoterpene group, i.e., $\alpha$-pinene $(48.3 \%)$ and sabinene $(8.4 \%)$, were found in juniper oil. $\alpha$-Pinene/sabinene-rich EO exhibits antimicrobial properties affecting microbial growth; with increasing concentrations of oil, the duration of the lag phase of bacterial growth may elongate (Tserennadmid

Table 7 RT-qPCR confirmation of relative expression level of genes encoding lipases in Pseudomonas fluorescens KM24 grown in fish juice medium enriched with juniper essential oil, $\alpha$-pinene, and sabinene

\begin{tabular}{|c|c|c|c|c|c|c|}
\hline \multirow[t]{3}{*}{$\begin{array}{l}\text { Time of incubation } \\
\text { (days) }\end{array}$} & \multicolumn{2}{|c|}{$\begin{array}{l}\text { Fish juice } \\
\text { medium } \\
\text { supplemented } \\
\text { with juniper } \\
\text { EO }\end{array}$} & \multicolumn{2}{|c|}{$\begin{array}{l}\text { Fish juice } \\
\text { medium } \\
\text { supplemented } \\
\text { with } \alpha \text {-pinene }\end{array}$} & \multicolumn{2}{|c|}{$\begin{array}{l}\text { Fish juice } \\
\text { medium } \\
\text { supplemented } \\
\text { with sabinene }\end{array}$} \\
\hline & \multicolumn{6}{|c|}{$\log _{2}$ (relative quantity) } \\
\hline & $\operatorname{lip} A$ & $\operatorname{lip} B$ & $\operatorname{lip} A$ & $\operatorname{lip} B$ & lipA & $\operatorname{lip} B$ \\
\hline 3 & -0.6 & -0.5 & -0.3 & -0.5 & -0.5 & -0.4 \\
\hline 5 & -0.6 & -0.5 & -0.5 & -0.5 & -0.6 & -0.6 \\
\hline
\end{tabular}

et al. 2010; Majewska et al. 2017; Salehi et al. 2019). Tserennadmid et al. (2010) also revealed changes in the maximum specific growth rate parameter of $B$. cereus exposed to juniper EO. These changes may also influence AHL production (Jiang et al. 2014). Taking the aforementioned facts into account, in this work, sub-MICs of juniper EO, $\alpha$-pinene, and sabinene were used as protective anti-QS agents against KM24, as concentrations above sub-MIC levels in foods could be sensorily unacceptable for consumers (Khan et al. 2009).

Determination of sub-MICs was performed by monitoring KM24 biomass buildup. In the study, concentrations of $120 \mu \mathrm{l}$ $\mathrm{ml}^{-1}, 40 \mu \mathrm{ml}^{-1}$, and $30 \mu \mathrm{ml}^{-1}$ of EO, $\alpha$-pinene, and sabinene, respectively, were selected for further investigation. SEM experiments revealed alteration of the morphology of KM24 after exposure to sub-MICs of the examined agents. According to Di Pasqua et al. (2007), selective compounds of EOs may cause structural changes to the outer envelope of bacteria, causing the envelope to appear rougher. Terpenes from EOs often induce swelling of gram-negative bacteria (Nazzaro et al. 2013).

Next, we verified the anti-QS activity of juniper EO, $\alpha$ pinene, and sabinene by the Blosser and Gray (2000) bioassay and an RP-UHPLC-ESI-MS system. All of the agents examined significantly inhibited QS autoinducer synthesis in the KM24 strain; at all the experimental time points, the agents affected CV026 pigment production and decreased the concentrations of all of the identified AHLs to levels lower than the limit of detection. In the reference culture at 5 days of incubation, the QS autoinducer profile of KM24 consisted of the following molecules: 3-oxo-C14-HSL, 3-oxo-C6-HSL, and $N$-[(RS)-3-hydroxybutyryl]-HSL, with C4-HSL as the major autoinducer whose content was specified at the level of $3.744 \mu \mathrm{g} \mathrm{ml}^{-1}$. The concentrations of 3-oxo-C14-HSL, 3oxo-C6-HSL, and $N$-[(RS)-3-hydroxybutyryl]-HSL in the reference culture were $0.570,0.018$, and $0.554 \mu \mathrm{g} \mathrm{ml}^{-1}$, respectively. Based on the works of Guo et al. (2015) and Hawver 
et al. (2016), it can be concluded that suppression of the synthesis of AHLs with acyl chain lengths ranging from $\mathrm{C} 4$ to $\mathrm{C} 6$ in KM24 by juniper EO, $\alpha$-pinene, and sabinene reduced violacein formation in the bioassay; however, inhibition of C4-HSL synthesis appears to be particularly significant. According to Swem et al. (2009) and Guo et al. (2015), C4HSL can induce the maximum synthesis of violacein in CV026 in comparison to cognate AHLs. In contrast, AHLs with acyl chain lengths ranging from $\mathrm{C} 10$ to $\mathrm{C} 14$ are either weak antagonists or are completely inactive in the CV026 strain (Swem et al. 2009). In this work, the anti-QS activity of juniper EO, $\alpha$-pinene, and sabinene at sub-MIC concentrations was also verified by RT-qPCR experiments. All examined agents influenced the mRNA levels of genes encoding acyltransferase in the KM24 culture. These results are in line with the observation of Alvarez et al. (2014), who also determined strong anti-QS properties of monoterpene-rich oregano EO. Selected concentrations of oregano EO inhibited violacein production and downregulated the Cvil gene encoding QS autoinducer synthase in C. violaceum (Alvarez et al. 2014). According to Deryabin et al. (2019), monoterpenes may reduce AHL synthesis both by affecting QS-related genes and by interacting with luxI-type proteins. The modeling data showed the interaction of plant-derived monoterpenes with acyltransferase with good stereochemical qualities (Deryabin et al. 2019; Sobieszczańska et al. 2020).

QS regulates proteolytic activity in Pseudomonas spp. (Sobieszczańska et al. 2020). This feature poses problems for the retention of quality seafood (Venugopal 1990). Several volatile odor-bearing compounds, such as volatile basic nitrogen compounds, volatile acids, $\mathrm{H}_{2} \mathrm{~S}$, and mercaptans, are produced in fish as a result of pseudomonad proteolytic activities (Xie et al. 2018). Our results showed that KM24 exhibited proteolytic activity at $4{ }^{\circ} \mathrm{C}$. However, with low levels of AHLs, noticeably reduced protease synthesis and downregulation of the $\operatorname{prl} C$ and $\operatorname{ctp} B$ genes were observed. These observations agree with the work of Ahmed et al. (2019), who revealed that downregulation of the lasI gene encoding synthase AHLs in Pseudomonas aeruginosa resulted in a decrease in protease activity. The sub-MIC level of plant-derived QS inhibitors did not completely inhibit protease expression and production, but their administration significantly reduced this phenotype at both the transcriptional and extracellular levels in P. aeruginosa (Ahmed et al. 2019). These observations further support the view that EOs and their major compounds that target AHL synthesis can be potential food biocides for reducing bacterial spoilage activities.

Finally, the anti-lipolytic activities of juniper EO, $\alpha$-pinene, and sabinene were evaluated. The lipolytic phenotype of Pseudomonas strains is also regulated by the QS system (Devescovi et al. 2007; Udine et al. 2013). Udine et al. (2013) revealed that supplementation of the culture medium with AHLs increased the transcription of lipA and lipB in
Burkholderia cenocepacia. Additionally, the lipase encoded by lipA of Burkholderia glumae is regulated by AHL QS; the strain lost its capacity to synthesize lipase since it contained a nonfunctional AHL QS system (Devescovi et al. 2007). The results of this study confirmed that the lipolytic activities of KM24 lead to AHL-controlled phenotypes. The QS inhibitors examined reduced the lipolytic activities of KM24 in the fishbased model at all the tested points, while a sub-MIC of juniper EO was the most efficient. Our work directly proves that juniper EO can be used for the biopreservation of cold-stored fishery products.

In conclusion, fish from catch to consumption are prone to contamination with cold-tolerant $P$. fluorescens. The proteases and lipases of these bacteria pose problems for the retention of quality and safety during the storage of seafood. The application of conventional chilling and mechanical refrigeration is not adequate to protect fishery products against the action of bacterial proteases and lipases. The results of this work directly indicate that the use of $\alpha$-pinene-/sabinene-rich juniper EO with anti-QS properties along with refrigeration could provide an additional advantage for controlling the spoilage activities of pseudomonads in fish.

Supplementary Information The online version contains supplementary material available at https://doi.org/10.1007/s00253-021-11338-3.

Authors' contributions $\mathrm{KM}, \mathrm{NT}, \mathrm{\iota W}, \mathrm{ASz}, \mathrm{AG}$, and MM conducted all the laboratory work, processed the data, and prepared them for publication; KN served her expertise in RNA-Seq experiments; KM conceived the concept of the study and wrote the manuscript.

Funding This study was funded by the National Science Centre, Poland (grant number 2016/23/D/NZ9/00028).

Data availability All data on which the conclusions were drawn are presented in this published article [and its electronic supplementary material].

\section{Declarations}

Ethical approval This article does not contain any studies with human participants or animal performed by any of the authors.

Consent for publication All the authors express consent for publication of the manuscript.

Conflict of interest The authors declare that they have no conflict of interest.

Open Access This article is licensed under a Creative Commons Attribution 4.0 International License, which permits use, sharing, adaptation, distribution and reproduction in any medium or format, as long as you give appropriate credit to the original author(s) and the source, provide a link to the Creative Commons licence, and indicate if changes were made. The images or other third party material in this article are included in the article's Creative Commons licence, unless indicated otherwise in a credit line to the material. If material is not included in the article's 
Creative Commons licence and your intended use is not permitted by statutory regulation or exceeds the permitted use, you will need to obtain permission directly from the copyright holder. To view a copy of this licence, visit http://creativecommons.org/licenses/by/4.0/.

\section{References}

Ackman RG (1994) Seafoods lipids. In: Shahidi F, Botta JR (eds) Seafoods: chemistry, processing, technology and, quality edn. MA pp, Springer, Boston, pp 34-48

Ahmed AAKS, Rudden M, Smyth TJ, Dooley JSG, Marchant R, Banat IM (2019) Natural quorum sensing inhibitors effectively downregulate gene expression of Pseudomonas aeruginos a virulence factors. Appl Microbiol Biotechnol 103:3521-3435. https://doi.org/10. 1007/s00253-019-09618-0

Alvarez MV, Ortega-Ramirez LA, Gutierrez-Pacheco MM, BernalMercado AT, Rodriguez-Gracia I, Gonzalez-Aguilar GA, Ponce A, del R, Moreira M, Roura SI, Ayala-Zavala JF (2014) Oregano essential oil-pectin edible films as anti-quorum sensing and food antimicrobial agents. Front Microbiol 5:699

Baysse C, Cullinane M, Denervaud V, Burrowes E, Dow JM, Morrissey JP, Tam I, Trevors JT, O'Gara F (2005) Modulation of quorum sensing in Pseudomonas aeruginosa through alteration of membrane properties. Microbiol 151:2529-2542. https://doi.org/10. 1099/mic.0.28185-0

Beven C-A, Dieckelmann M, Beacham IR (2001) A strain of Pseudomonas fluorescens with two lipase-encoding genes, one of which possibly encodes cytoplasmic lipolytic activity. J Appl Microbiol 90:979-987. https://doi.org/10.1046/j.1365-2672.2001. 01333.x

Blosser RS, Gray KM (2000) Extraction of violacein from Chromobacterium violaceum provides a new quantitative bioassay for $N$-acyl homoserine lactone autoinducers. J Microbiol Methods 40:47-55. https://doi.org/10.1016/s0167-7012(99)00136-0

Bradford MM (1976) A rapid and sensitive method for the quantification of microgram quantities of protein utilizing the principle of proteindye binding. Anal Biochem 7(72):248-254. https://doi.org/10.1006/ abio.1976.9999

Clinical and Laboratory Standards Institute, Annapolis Junction, MD (2012) Methods for dilution antimicrobial susceptibility tests for bacteria that grow aerobically, approved standards. $9^{\text {th }}$ edition.

Cvrtila Ž, Konjević D, Kozačinski L, Hadžiosmanović M, Slavica A, Margaletić J (2004) The chemical composition of the meat of fat dormice (Glis glis L.). Eur J Wildl Res 50:90-91. https://doi.org/10. 1007/s10344-004-0046-z

Deryabin D, Galadzhieva A, Kosyan D, Duskaev G (2019) Plant-derived inhibitors of AHL-mediated quorum sensing in bacteria: modes of action. Int J Mol Sci 20:5588. https://doi.org/10.3390/ijms20225588

Devescovi G, Bigirimana J, Degrassi G, Cabrio L, LiPuma JJ, Kim J, Hwang I, Venturi V (2007) Involvement of a quorum sensingregulated lipase secreted by a clinical isolate of Burkholderia glumae in severe disease symptoms in rice. Appl Environ Microbiol 73(15):4950-4958. https://doi.org/10.1128/AEM. 00105-07

Di Pasqua R, Betts G, Hoskins N, Edwards M, Ercolini D, Mauriello G (2007) Membrane toxicity of antimicrobial compounds from essential oils. J Agric Food Chem 55:4863-4870. https://doi.org/10.1021/ jf0636465

Dieckelmann M, Johnson LA, Beacham IR (1998) The diversity of lipases from psychrotrophic strains of Pseudomonas: a novel lipase from a highly lipolytic strain of Pseudomonas fluorescens. J Appl Microbiol 85:527-536. https://doi.org/10.1046/j.1365-2672.1998. 853530.x
Falleh H, Jemaa MB, Saaba M, Ksouri R (2020) Essential oils: a promising eco-friendly food preservative. Food Chem 330:127268. https://doi.org/10.1016/j.foodchem.2020.127268

Ghaly AE, Dave D, Budge S, Brooks MS (2010) Fish spoilage mechanisms and preservation techniques: review. Am J Appl Sci 7(7): 859-877. https://doi.org/10.3844/ajassp.2010.859.877

Guo M, Zheng Y, Starks R, Opoku-Temeng C, Ma X, Sintim HO (2015) 3-Aminooxazolidinone AHL analogs as hydrolytically-stable quorum sensing agonists in Gram-negative bacteria. Med Chem Commun 6:1086-1092. https://doi.org/10.1039/c5md00015g

Haard NF (1994) Protein hydrolysis in seafoods. In: Shahidi F, Botta JR (eds) Seafoods: chemistry, processing, technology and quality edn. MA pp, Springer, Boston, pp 10-33

Hawver LA, Jung SA, Ng W-L (2016) Specificity and complexity in bacterial quorum-sensing systems. FEMS Microbiol Rev 40(5): 738-752. https://doi.org/10.1093/femsre/fuw014

Höferl M, Stoilova I, Schmidt E, Wanner J, Jirovetz L, Trifonova D, Krastev L, Krastanov A (2014) Chemical composition and antioxidant properties of juniper berry (Juniperus communis L.) essential oil. Action of the essential oil on the antioxidant protection of Saccharomyces cerevisiae model organism. Antioxidants 3:81-98. https://doi.org/10.3390/antiox3010081

Jiang J, Wu S, Wang J, Feng Y (2014) AHL-type quorum sensing and its regulation on symplasmata formation in Pantoea agglomerans YS19. J Basic Microbiol 54:1-10. https://doi.org/10.1002/jobm. 201400472

Kerekes EB, Deács Ě, Takó M, Tserennadmid R, Petkovits T, Vágvölgyi C (2013) Anti-biofilm forming and anti-quorum sensing activity of selected essential oils and their main components on food-related microorganisms. J Appl Microbiol 115:933-942. https://doi.org/10. 1111/jam. 12289

Khan MSA, Zahin M, Hasan S, Husain FM, Ahmad I (2009) Inhibition of quorum sensing regulated bacterial functions by plant essential oils with special reference to clove oil. Lett Appl Microbiol 49:354-360. https://doi.org/10.1111/j.1472-765X.2009.02666.x

Laue BE, Jiang Y, Chhabra SR, Jacob S, Stewart GS, Hardman A, Dowinie JA, O'Gara F, Williams P (2000) The biocontrol strain Pseudomonas fluorescens $\mathrm{F} 113$ produces the Rhizobium small bacteriocin, N-(3-hydroxy-7-cis-tetradecenoyl)homoserine lactone, via $\mathrm{HdtS}$, a putative novel $\mathrm{N}$-acylhomoserine lactone synthase. Microbiol 146:2469-2480. https://doi.org/10.1099/00221287-14610-2469

Lee J, Zhang L (2015) The hierarchy quorum sensing network in Pseudomonas aeruginosa. Protein Cell 6:26-41. https://doi.org/10. 1007/s13238-014-0100-x

Love DC, Fry JP, Milli MC, Neff RA (2015) Wasted seafood in the United States: quantifying loss from production to consumption and moving toward solutions. Glob Environ Chang 35:116-124. https://doi.org/10.1016/j.gloenvcha.2015.08.013

Majewska E, Kozłowska M, Kowalska D, Gruczyńska E (2017) Characterization of the essential oil from cone-berries of Juniperus communis L. (Cupressaceae). Herba Pol 63(3):48-55. https://doi. org/10.1515/hepo-2017-0018

Martínez A, Soberón-Chávez G (2001) Characterization of the lipA gene encoding the major lipase from Pseudomonas aeruginosa strain IGB83. Appl Microbiol Biotechnol 56:731-735. https://doi.org/10. $1007 / \mathrm{s} 002530100724$

Montagne P (1999) The concise Larousse Gastronomique. Hamlyn, London, UK pp691-692

Møretro T, Moen B, Heir E, Hansen AA, Langsurd S (2016) Contamination of salmon fillets and processing plants with spoilage bacteria. Int J Food Microbiol 237:98-108. https://doi.org/10.1016/ j.ijfoodmicro.2016.08.016

Myszka K, Sobieszczańska N, Olejnik A, Majcher M, Szwengiel A, Wolko Ł, Juzwa W (2020) Studies on the anti-proliferative and anti-quorum sensing potentials of Myrtus communis L. essential 
oil for the improved microbial stability of salmon-based products. LWT 127:109380. https://doi.org/10.1016/j.lwt.2020.109380

Nazzaro F, Fratianni F, De Martino L, Coppola R, De Feo V (2013) Effect of essential oils on pathogenic bacteria. Pharmaceuticals 6: 1451-1474. https://doi.org/10.3390/ph6121451

Papenfort K, Bassler B (2016) Quorum-sensing signal-response systems in gram-negative bacteria. Nat Rev Microbiol 14:576-588. https:// doi.org/10.1038/nrmicro.2016.89

Polychroniadou A (1988) A simple procedure using trinitrobenzenesulphonic acid for monitoring proteolysis in cheese. J Dairy Res 55:585-596. https://doi.org/10.1017/ S0022029900033379

Ravn L, Christensen AB, Molin S, Givskov M, Gram L (2001) Methods for detecting acylated homoserine lactones produced by gramnegative bacteria and their application in studies of AHLproduction kinetics. J Microbiol Methods 44:239-251. https://doi. org/10.1016/S0167-70129(01)00217-2

Salehi B, Upadhyay S, Orhan IE, Jugran AK, Jayaweera SLD, Dias DA, Sharopov F, Taheri Y, Martins N, Baghalpour N, Cho WC, SharifiRad J (2019) Therapeutic potential of $\alpha$ - and $\beta$-pinene: a miracle gift of nature. Biomolecules 9:738. https://doi.org/10.3390/ biom9110738

Schmittgen TD, Livak K (2008) Analyzing real-time PCR data by the comperative $\mathrm{C}_{\mathrm{t}}$ method. Nat Protoc 3:1101-1108. https://doi.org/10. 1038/nprot.2008.73

Šimunović K, Ramić G, Xu C, Smole Možina S (2020) Modulation of Campylobacter jejuni motility, adhesion to polystyrene surfaces, and invasion of INT407 cells by quorum sensing inhibition. Microorganisms 8(1):e104. https://doi.org/10.3390/ microorganisms 8010104

Sobieszczańska N, Myszka K, Szwengiel A, Majcher M, Grygier A, Wolko $Ł$ (2020) Tarragon essential oil as a source of bioactive compounds with anti-quorum sensing and anti-proteolytic activity against Pseudomonas spp. isolated from fish - in vitro, in silico, and in situ approaches. Int J Food Microbiol 331:108732. https://doi.org/ 10.1060/j.ijfoodmicro.2020.108732

Stuer W, Jaeger KE, Winkler UK (1986) Purification of extracellular lipase from Pseudomonas aeruginosa. J Bacteriol 168(3):1070 1074. https://doi.org/10.1128/jb.168.3.1070-1074.1986

Swem LR, Swem DL, O’Loughlin CT, Gatmaitan R, Zhao B, Ulrich SM, Bassler BL (2009) A quorum-sensing antagonist targets both membrane-bound and cytoplasmic receptors and controls bacterial pathogenicity. Mol Cell 35(2):143-153. https://doi.org/10.1016/j. molcel.2009.05.029
Tserennadmid R, Takó M, Galgóczy L, Papp T, Vágvölgyi C, Gerő L, Krisch J (2010) Antibacterial effect of essential oils and interaction with food components. Cent Eur J Biol 5(5):641-648. https://doi. org/10.2478/s11535-010-0058-5

Tsuyuki H, Roberts E, Gadd REA (1962) Muscle proteins of pacific salmon (Oncorhynchus): II. An investigation of muscle protein and other substances soluble in salt solutions of low ionic strength by column chromatography. Can J Biochem Physiol 40(7):919927. https://doi.org/10.1139/o62-103

Tzortzakis NG, Economakis C (2007) Antifungal activity of lemongrass (Cympopogon citratus L.) essential oil against key postharvest pathogens. In Food Sci Emerging Technol 8(2):253-258. https://doi.org/ 10.1016/j.ifset.2007.01.002

Udine C, Brackman G, Bazzini S, Buroni S, Van Acker H, Pasca MR, Riccardi G, Coenye T (2013) Phenotypic and genotypic characterization of Burkholderia cenocepacia J2315 mutants affected in homoserine lactone and diffusible signal factor-based quorum sensing systems suggests interplay between both types of systems. PLoS One 8(1):e55112. https://doi.org/10.1371/journal.pone.0055112

Venugopal V (1990) Extracellular proteases of contaminant bacteria in fish spoilage: a review. J Food Prot 53(4):341-350. https://doi.org/ 10.4315/0362-028X-53.4.341

Woods RG, Burger M, Beven C-A, Beacham IR (2001) The aprX-lipA operon of Pseudomonas fluorescens B52: a molecular analysis of metalloprotease and lipase production. Microbiol 147:345-354. https://doi.org/10.1099/00221287-147-2-345

Xie J, Zhang Z, Yang S-P, Cheng Y, Qian Y-F (2018) Study on the spoilage potential of Pseudomonas fluorescens on salmon stored at different temperatures. J Food Sci Technol 55(1):217-225. https://doi.org/10.1007/s13197-017-2916-x

Yeom DH, Kim S-K, Lee M-N, Lee J-H (2013) Pleiotropic effects of acyltransferases on various virulence-related phenotypes of Pseudomonas aeruginosa. Genes Cells 18:682-693. https://doi. org/10.1111/gtc. 12076

Zhang X, Ning X, He X, Sun X, Yu X, Cheng Y, Yu R-Q, Wu Y (2020) Fatty acid composition analyses of commercially important fish species from the Pearl River Estuary, China. PLoS One 15(1): e0228276. https://doi.org/10.1371/journal.prone.0228276

Publisher's note Springer Nature remains neutral with regard to jurisdictional claims in published maps and institutional affiliations. 